\title{
Autoimmunity as an etiology of fulminant type 1 diabetes
}

\author{
Akira Shimada ${ }^{1}$ (D)
}

Received: 16 February 2016/Published online: 9 March 2016

(C) The Japan Diabetes Society 2016

Fulminant type 1 diabetes was first described by Imagawa et al. in 2000 as a "nonautoimmune" subtype of type 1 diabetes [1]. Characteristics of fulminant type 1 diabetes proposed in the original report are as follows:

1. Abrupt onset of diabetic ketoacidosis

2. Relatively low glycosylated hemoglobin $\left(\mathrm{HbA}_{1 \mathrm{c}}\right)$ level despite high plasma glucose level

3. Absence of insulin secretion

4. Elevated serum pancreatic enzyme level

5. Negativity of glutamic acid decarboxylase (GAD) antibody

In fulminant type 1 diabetic patients who survived and the pancreas was examined histologically by biopsy within 5 months postonset, there was no insulitis, but T-cell infiltration was observed in exocrine tissue. Because $60-70 \%$ of fulminant type 1 diabetic patients have a history of flu-like symptoms before the onset of diabetes, a certain viral infection was suspected as the etiological mechanism. In fact, immunoglobulin A (IgA) antibody titer of enterovirus is elevated in fulminant type 1 diabetes [2], and reactivation of human herpesvirus 6 (HHV-6) may cause fulminant type 1 diabetes in drug-induced hypersensitivity syndrome [3]. Moreover, encephalomyocarditis (EMC) virus induced a fulminant type 1 diabetes-like phenotype in a certain mouse strain [4]. These reports suggest the concept that fulminant type 1 diabetes may be caused by viral infection. However, it has been reported that CD8-dominant T-cell insulitis was clearly observed in

Akira Shimada

asmd3874@gmail.com

1 Department of Endocrinology and Diabetes, Saitama Medical University, 38 Morohongo, Moroyama, Iruma, Saitama 350-0495, Japan a fulminant type 1 diabetic patient who died right after the onset of diabetes [5], suggesting it may be caused by an autoimmune mechanism. Moreover, later studies indicated that islet-associated autoantibody may appear several months after disease onset [6], and T-cell reactivity to isletassociated antigen is also detected [7]. Moreover, recent data indicate that islet-associated antibodies are detected in $18 \%$ of patients with fulminant type 1 diabetes [8], again suggesting it may be caused by autoimmunity. In a rodent model, a fulminant type 1 diabetes-like phenotype was observed in poly(I:C), mimic of double-stranded RNA (dsRNA)-injected CD28 knockout nonobese diabetic (NOD) mice, indicating that a fulminant type 1 diabeteslike phenotype can be induced in a mouse model of autoimmune diabetes [9]. CD28 knockout NOD mice possess a very low number of regulatory $\mathrm{T}$ cells compared with conventional NOD mice, and poly(I:C) injection is used to mimic RNA virus infection. In this model, not only beta cells but also alpha cells were reduced, and T-cell infiltration of exocrine tissue was observed, as in human fulminant type 1 diabetes. Therefore, viral infection may trigger the disease in regulatory T-cell-deficient autoimmune diabetes. In this situation, very recent reports have shown that anti-PD-1 antibody treatment for malignancies such as melanoma resulted in fulminant type 1 diabetes [10]. T cells are deactivated through inhibitory signals such as PD-1 and the ligand PD-L1 [11]. PD-1 inhibition by anti-PD-1 antibody is likely to trigger an autoimmune phenomenon. Therefore, these reports also strongly support the autoimmunity hypothesis. Moreover, importantly, these cases are reported in the Caucasian population, in which the disease is reported to be very rare [12]; thus far, it is mainly reported in Japanese but also in the other Asian populations, such as Koreans [13], Chinese [14], and Filipinos [15]. However, case reports of anti-PD-1 antibody- 
triggered fulminant type 1 diabetes indicate that it is also seen in the Caucasian population and thus may be a global disease. The etiology of fulminant type 1 diabetes should be discussed worldwide in order to overcome this fatal subtype of type 1 diabetes.

\section{Compliance with ethical standards}

Conflict of interest statement Akira Shimada received lecture fees from Novo Nordisk, Eli Lilly, and Sanofi.

Human rights statement and informed consent This article does not contain any studies with humans or animals performed by any of the authors.

\section{References}

1. Imagawa A, Hanafusa T, Miyagawa J, Matsuzawa Y. A novel subtype of type 1 diabetes mellitus characterized by a rapid onset and an absence of diabetes-related antibodies. Osaka IDDM Study Group. N Engl J Med. 2000;342:301-7.

2. Imagawa A, Hanafusa T, Makino H, Miyagawa JI, Juto P. High titres of IgA antibodies to enterovirus in fulminant type-1 diabetes. Diabetologia. 2005;48:290-3.

3. Sekine N, Motokura T, Oki T, Umeda Y, Sasaki N, Hayashi M, Sato H, Fujita T, Kaneko T, Asano Y, Kikuchi K. Rapid loss of insulin secretion in a patient with fulminant type 1 diabetes mellitus and carbamazepine hypersensitivity syndrome. JAMA. 2001;285:1153-4.

4. Shimada A, Maruyama T. Encephalomyocarditis-virus-induced diabetes model resembles "fulminant" type 1 diabetes in humans. Diabetologia. 2004;47:1854-5.

5. Tanaka S, Kobayashi T, Momotsu T. A novel subtype of type 1 diabetes mellitus. N Engl J Med. 2000;342:1835-7.
6. Shimada A, Oikawa Y, Shigihara T, Senda T, Kodama K. A case of fulminant type 1 diabetes with strong evidence of autoimmunity. Diabetes Care. 2002;25:1482-3.

7. Shimada A, Morimoto J, Kodama K, Oikawa Y, Irie J, Nakagawa Y, Narumi S, Saruta T. T-cell-mediated autoimmunity may be involved in fulminant type 1 diabetes. Diabetes Care. 2002;25:635-6.

8. Kawasaki E, Nakamura K, Kuriya G, Satoh T, Kobayashi M, Kuwahara H, Abiru N, Yamasaki H, Matsuura N, Miura J, Uchigata Y, Eguchi K. Differences in the humoral autoreactivity to zinc transporter 8 between childhood- and adult-onset type 1 diabetes in Japanese patients. Clin Immunol. 2011;138:146-53.

9. Tada A, Shimada A, Yamada T, Oikawa Y, Yamada Y, Okubo Y, Irie $\mathrm{J}$, Bluestone $\mathrm{JA}$, Itoh $\mathrm{H}$. A mimic of viral double-stranded RNA triggers fulminant type 1 diabetes-like syndrome in regulatory $\mathrm{T}$ cell-deficient autoimmune diabetic mouse. J Immunol. 2011;187:4947-53.

10. Gaudy C, Clévy C, Monestier S, Dubois N, Préau Y, Mallet S, Richard MA, Grob JJ, Valéro R, Béliard S. Anti-PD1 pembrolizumab can induce exceptional fulminant type 1 diabetes. Diabetes Care. 2015;38:e182-3.

11. Mellati M, Eaton KD, Brooks-Worrell BM, Hagopian WA, Martins R, Palmer JP, Hirsch IB. Anti-PD-1 and Anti-PDL-1 monoclonal antibodies causing type 1 diabetes. Diabetes Care. 2015;38:e137-8.

12. Pozzilli P, Visalli N, Leslie D. No evidence of rapid onset (Japanese) type 1 diabetes in caucasian patients. IMDIAB Group. Diabetologia. 2000;43:1332.

13. Jung TS, Chung SI, Kim MA, Kim SJ, Park MH, Kim DR, Kang MY, Hahm JR. A Korean patient with fulminant autoantibodynegative type 1 diabetes. Diabetes Care. 2004;27:3023-4.

14. Katsumata K, Katsumata K. A Chinese patient presenting with clinical signs of fulminant type 1 diabetes mellitus. Intern Med. 2005;44:967-9.

15. Taniyama M, Katsumata R, Aoki K, Suzuki S. A Filipino patient with fulminant type 1 diabetes. Diabetes Care. 2004;27:842-3. 